\title{
Faktor - Faktor Yang Mempengaruhi Status Imunisasi Dasar Pada Anak Usia 12 -24 Bulan
}

\author{
Yulinda Aswan ${ }^{1}$, Febrina Anggraini Simamora ${ }^{2}$ \\ STIKes Aufa Royhan Padangsidimpuan ${ }^{123}$ \\ e-mail: 'yulindaa0@gmail.com
}

\begin{abstract}
Immunization is the provision of immunity to children against certain diseases that can be prevented by immunization before the age of 12 months. Complete and regular basic immunizations are obtained when a child is less than 11 months old. Immunization can reduce morbidity and mortality for children by 80-95\%. Incomplete basic immunization, maximum can only provide protection against disease that is equal to $25-40 \%$. This study aims to determine the factors that influence mothers towards basic immunization status in children aged 12-24 months in the Labuhan Rasoki Padangsidimpuan Southeast Health Center. This research was conducted using descriptive correlation design with cross sectional approach. The population is all mothers who have children aged 12-24 months and bring their children immunized. The number of samples as many as 40 people with total sampling techniques. The results showed from the demographic data of 40 respondents, the majority of mothers aged $\leq 30$ years as much as 45\%, the majority of mothers with secondary education as much as 50\%, the majority of multiparous mothers as much as $40 \%$, the majority of middle and upper income mothers as much as 40\%, the majority of mothers with less knowledge as much as $67,5 \%$, and $60 \%$ complete basic childhood immunization status. Chi square statistical test results revealed that there was no significant relationship between factors of age, education, occupation, number of children, income, and mother's knowledge of the basic immunization status in children ( $p>0.05)$.
\end{abstract}

Keywords: Basic immunization, Influencing Factors, Children 12 - 24 Months

\begin{abstract}
ABSTRAK
Imunisasi merupakan pemberian kekebalan kepada anak terhadap penyakit tertentu yang dapat dicegah dengan imunisasi sebelum berusia 12 bulan. Imunisasi dasar lengkap dan teratur didapat pada waktu anak berusia kurang dari 11 bulan. Imunisasi dapat mengurangi angka kesakitan dan kematian anak sekitar 80-95\%. Imunisasi dasar yang tidak lengkap, maksimum hanya dapat memberikan perlindungan terhadap penyakit yaitu sebesar $25-40 \%$. Penelitian ini bertujuan untuk mengetahui faktor-faktor yang mempengaruhi ibu terhadap status imunisasi dasar pada anak usia 12-24 bulan di Puskesmas Labuhan Rasoki Padangsidimpuan Tenggara. Penelitian ini dilakukan menggunakan desain korelasi deskriptif dengan pendekatan cross sectional. Populasi yaitu seluruh ibu yang mempunyai anak usia 12-24 bulan dan membawa anaknya imunisasi. Jumlah sampel sebanyak 40 orang dengan tekhnik total sampling. Hasil penelitian menunjukkan dari data demografi dari 40 responden, mayoritas ibu berusia $\leq 30$ tahun sebanyak $45 \%$, mayoritas ibu berpendidikan menengah sebanyak $50 \%$, mayoritas ibu multipara sebanyak 40\%, mayoritas ibu berpenghasilan menengah keatas sebanyak 40\%, mayoritas ibu berpengetahuan kurang sebanyak 67,5\%, serta status imunisasi dasar anak yang lengkap $60 \%$. Hasil uji statistik chi square diketahui bahwa tidak terdapat hubungan yang bermakna antara faktor usia, pendidikan, pekerjaan, jumlah anak, penghasilan, dan pengetahuan ibu terhadap status imunisasi dasar pada anak $(\mathrm{p}>0,05)$.
\end{abstract}

Kata kunci: Imunisasi dasar, Faktor-faktor yang Mempengaruhi, Anak Usia 12 - 24 Bulan

\section{PENDAHULUAN}

Pembangunan nasional jangka panjang menitik beratkan pada kualitas hidup sumber daya manusia yang prima.Untuk itu kita bertumpu pada generasi muda yang memerlukan asuhan dan perlindungan terhadap penyakit yang mungkin dapat menghambat tumbuh kembangnya menuju dewasa yang berkualitas tinggi guna meneruskan pembangunan nasional jangka panjang tersebut salah satu perwujudannya dengan meningkatkan status imunisasi. ${ }^{(2)}$

Pada tahun 2010 sekitar 2,5 juta kematian diperkirakan setiap tahun di usia kelompok bayi dari difteri, pertusis, tetanus dan campak. Cakupan 
imunisasi di wilayah Asia Tenggara mencapai 52\%. Cakupan imunisasi anak di Negara-Negara anggota WHO telah mencapai $90 \%$, dan diperkirakan $85 \%$ dari bayi diseluruh dunia telah mendapat imunisasi. Terdapat 19,3\% juta bayi dan anak-anak belum sepenuhnya mendapatkan vaksinasi dan tetap beresiko terkena penyakit. ${ }^{(1)}$

Salah satu tujuan MDGs pada poin keempat adalah menurunkan angka kematian bayi adalah dengan meningkatkan status imunisasi terutama imunisasi dasar lengkap pada balita yang hingga saat ini status balita yang mendapatkan imunisasi lengkap belum optimal padahal imunisasi merupakan hal yang wajib untuk bayi dengan imunisasi wajib maka bayi akan terlindung terhadap penyakit yang kerap menyerang. ${ }^{(3)}$

Imunisasi merupakan salah satu bentuk intervensi kesehatan yang sangat efektif dalam upaya menurunkan angka kematian bayi dan balita. Berbagai macam penyakit menular seperti penyakit dipteri, pertusis, campak, tetanus, dan polio telah terbukti menurun berkat pemberian imunisasi. Jadi, pemberian imunisasi merupakan hal yang sangat penting. ${ }^{(3)}$

Adapun persentase anak usia 1 tahun yang diimunisasi campak dengan acuan dasar (1991) sebesar 44,5\% (SDKI), tahun (2007) sebesar 67.0\% (SDKI), dan target nasional (2014) 93\% (RKP 2011). Pada tahun 1991 angka kematian balita mencapai 97 kematian per 1.000 kelahiran hidup. Pada tahun 20022003 angka kematian tersebut jauh menurun menjadi 46 per 1.000 kelahiran hidup,dan pada tahun 2007 turun menjadi 44 kematian per 1.000 kelahiran hidup. (1)

Data SDKI 2007 menunjukkan bahwa terdapat 18 provinsi dengan cakupan imunisasi campak lebih rendah dari rata-rata nasional, yaitu dibawah $67.0 \%$. Provinsi dengan cakupan terendah adalah Sumatera Utara 36,6\%, Aceh 40,9\%, dan Papua 49,9\%. Sedangkan provinsi dengan cakupan tertinggi adalah DIY dengan cakupan $94,8 \%$. $^{(1)}$

Angka kematian bayi (AKB) dalam dua dasawarsa terakhir ini menunjukkan penurunan yang bermakna. Apabila pada tahun 1971 sampai dengan tahun 1980 memerlukan sepuluh tahun untuk menurunkan AKB dari 142 menjadi 112 per 1000 kelahiran hidup, maka hanya dalam kurun waktu lima tahun yaitu tahun 1985 sampai 1990 indonesia berhasil menurunkan AKB dari 71 menjadi 54 dan bahkan dari data 2001 telah menunjukkan angka 48 per 1000 kelahiran hidup. ${ }^{(5)}$

Jangkauan cakupan program imunisasi telah meningkat secara bertahap namun demikian, untuk beberapa jenis imunisasi mengalami penurunan. Selama periode 2002-2005, jangkauan program imunisasi utama yaitu TB, DPT3, dan hepatitis masing-masing meningkat sebanyak $6.17 \%$ dan $7 \%$. Tetapi hal ini diikuti oleh turunnya tingkat pemberian imunisasi polio, dan campak dari masing-masing 74 dan $76 \%$ menjadi $70 \%$, jangkauan imunisasi dasar lengkap masih tercatat dibawah $50 \%$. $^{(6)}$

Peran ibu pada program imunisasi ibu sangatlah penting karena penggunaan sarana kesehatan oleh anak berkaitan erat dengan faktor ibu. Rendahnya cakupan imunisasi disebabkan beberapa faktor. Ibu yang berusia $\geq 30$ tahun cenderung untuk tidak melakukan imunisasi lengkap dibanding ibu yang berusia $<30$ tahun, pendidikan tinggi berkaitan erat dengan pemberian imunisasi anak. ${ }^{(6)}$

Semakin banyak jumlah anak terutama ibu yang masih mempunyai bayi yang merupakan anak ketiga atau lebih akan membutuhkan banyak waktu untuk mengurus anak-anaknya tersebut sehingga semakin sedikit ketersediaan waktu bagi ibu untuk mendatangi tempat pelayanan imunisasi. ${ }^{(8)}$

Oleh karena itu penelitian ini dilakukan untuk mengetahui Faktor-faktor yang Mempengaruhi Ibu Terhadap Status Imunisasi Dasar pada Anak Usia 1224 Bulan di Puskesmas Labuhan Rasoki Padangsidimpuan Tenggara.

\section{METODE}

Penelitian ini menggunakan metode deskriptif analitik dengan pendekatan cross sectional, untuk mengidentifikasi tetang status imunisasi dasar pada anak usia 12-24 bulan di Puskesmas Labuhan Rasoki Padangsidimpaun Tenggara. Penelitian ini dilaksanakan mulai bulan Juni sampai Agustus 2018. Instrumen penelitian berupa kuesioner yang dibuat sendiri oleh peneliti dengan sejumlah pertanyaan tertulis yang telah tersusun secara terstruktur berdasarkan tinjauan teoritis yang terdiri dari : data ibu yang meliputi usia, pendidikan, pekerjaan, jumlah anak dan penghasilan ibu.

Kuesioner pengetahuan sebanyak 25 pertanyaan berisi tentang pengertian imunisasi, tujuan imunisasi, tempat imunisasi, yang dapat memberikan imunisasi, jenis-jenis imunisasi, penyakit yang dapat dicegah, jumlah pemberian, jadwal pemberian, dan lokasi penyuntikan. Kuesioner telah diuji coba dilapangan uji validitas dan uji realibilitas pada 15 responden dengan kriteria yang sama dengan yang akan diteliti. Hasil uji reliabilitas Cronbach's Alpha sebesar $0,763(\mathrm{r}=0.60)$.

\section{HASIL}

\section{a. Analisis Univariat}

Berdasarkan karakteristik responden yang mempunyai anak usia 12-24 bulan, responden yang dilibatkan dalam penelitian ini adalah sebanyak 40 orang seperti pada tabel dibawah ini.

\section{Tabel 1 Distribusi Frekuensi Karakteristik Responden}

\begin{tabular}{llll}
\hline No & $\begin{array}{l}\text { Karakteristik } \\
\text { Responden }\end{array}$ & N & (\%) \\
\hline
\end{tabular}




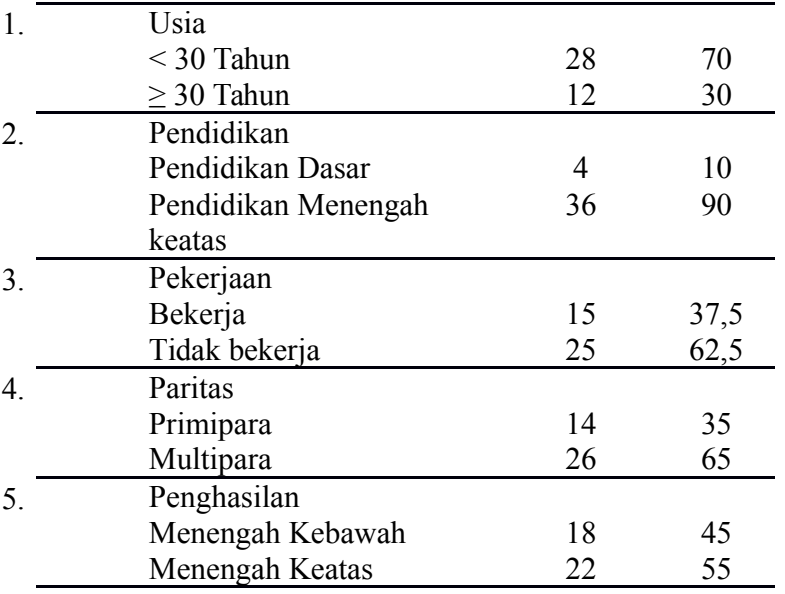

Distribusi Frekuensi Berdasarkan Pengetahuan Responden

Dari penelitian yang dilakukan terhadap status imunisasi dasar pada anak usia 12-24 bulan diperoleh hasil seperti pada tabel dibawah ini.

Tabel 2 Distribusi Frekuensi berdasarkan Pengetahuan Responden

\begin{tabular}{cccc}
\hline No. & $\begin{array}{c}\text { Pengetahuan } \\
\text { Responden }\end{array}$ & n & \% \\
\hline 1. & Baik & 13 & 32,5 \\
2. & Kurang & 27 & 67,5 \\
\hline & Jumlah & 40 & 100 \\
\hline
\end{tabular}

Distribusi Frekuensi Berdasarkan Status Imunisasi Dasar pada Anak

Dari penelitian yang dilakukan terhadap status imunisasi dasar pada anak usia 12-24 bulan diperoleh hasil seperti pada tabel dibawah ini.

Tabel 3 Distribusi Frekuensi Berdasarkan Status Imunisasi Dasar pada Anak

\begin{tabular}{cccc}
\hline No. & $\begin{array}{c}\text { Status Imunisasi } \\
\text { Dasar Pada Anak }\end{array}$ & n & (\%) \\
\hline 1. & Lengkap & 24 & 60 \\
2. & Tidak Lengkap & 16 & 40 \\
\hline & Jumlah & 40 & 100 \\
\hline
\end{tabular}

b. Analisis Bivariat

Analisis Hubungan Faktor Usia Ibu dengan Status Imunisasi Dasar pada Anak Usia 12-24 Bulan

Penelitian yang dilakukan tentang analisis hubungan faktor usia ibu dengan status imunisasi dasar pada anak diperoleh hasil seperti pada tabel dibawah ini :

Tabel 4 Analisis Hubungan Faktor Usia Ibu dengan Status Imunisasi Dasar pada Anak Usia 12-24 Bulan

\begin{tabular}{|c|c|c|c|}
\hline \multirow[t]{2}{*}{ Usia } & \multicolumn{2}{|c|}{ Status Imunisasi Dasar } & \multirow{2}{*}{$\begin{array}{c}p \\
\text { value }\end{array}$} \\
\hline & Lengkap & $\begin{array}{c}\text { Tidak } \\
\text { Lengkap }\end{array}$ & \\
\hline
\end{tabular}

\begin{tabular}{cccccc}
\hline & n & \% & n & \% & \\
\hline$<30$ tahun) & 18 & 45 & 10 & 25 & \multirow{2}{*}{0,49} \\
$\geq 30$ tahun & 6 & 15 & 6 & 15 & \\
\hline Total & 24 & 60 & 16 & 100 & \\
\hline
\end{tabular}

Pada table dapat dilihat bahwa status imunisasi dasar lengkap paling banyak di temukan pada kelompok umur $<30$ tahun sebanyak 18 orang $(45 \%)$. Dari hasil uji statistik diperoleh $p$ value $(0,490)$, maka dapat disimpulkan bahwa tidak ada hubungan yang signifikan antara faktor usia ibu dengan status imunisasi dasar pada anak usia 12-23 bulan.

Analisis Hubungan Faktor Pendidikan Ibu dengan Status Imunisasi Dasar pada Anak Usia 12-24 Bulan

Penelitian yang dilakukan tentang analisis hubungan faktor pendidikan ibu dengan status imunisasi dasar pada anak usia 12-23 bulan diperoleh hasil seperti pada tabel dibawah ini :

Tabel 5 Analisis Hubungan Faktor Pendidikan Ibu dengan Status Imunisasi Dasar pada Anak Usia 12-24 Bulan

\begin{tabular}{cccccc}
\hline \multirow{2}{*}{ Pendidikan } & \multicolumn{3}{c}{ Status Imunisasi Dasar } & \multirow{2}{*}{$\begin{array}{c}\text { Tidak } \\
\text { Lengkap }\end{array}$} & value \\
\cline { 2 - 5 } & $\mathbf{n}$ & $\mathbf{\%}$ & $\mathbf{n}$ & $\mathbf{\%}$ & \\
\cline { 2 - 5 } & 4 & 10 & 0 & 0 & \\
\hline $\begin{array}{c}\text { Pendidikan Dasar } \\
\text { Pendidikan }\end{array}$ & 20 & 50 & 16 & 40 & 0,136 \\
Menengah keatas & 24 & 60 & 16 & 40 & \\
\hline Total & &
\end{tabular}

Pada table dapat dilihat bahwa status imunisasi dasar lengkap paling banyak pada tingkat pendidikan menengah keatas sebanyak 20 orang $(50 \%)$ dengan hasil uji statistik diperoleh $p$ value $(0,136)$.

Analisis Hubungan Faktor Pekerjaan Ibu dengan Status Imunisasi Dasar pada Anak Usia 12-24 Bulan

Penelitian yang dilakukan tentang analisis hubungan faktor pekerjaan ibu dengan status imunisasi dasar pada anak usia 12-24 bulan diperoleh hasil seperti pada tabel dibawah ini :

Tabel 6 Analisis Hubungan Faktor Pekerjaan Ibu dengan Status Imunisasi Dasar pada Anak Usia 12-24 Bulan

\begin{tabular}{cccccc}
\hline \multirow{2}{*}{ Pekerjaan } & \multicolumn{3}{c}{ Status Imunisasi Dasar } & \\
\cline { 2 - 4 } & \multicolumn{2}{c}{ Lengkap } & \multicolumn{2}{c}{$\begin{array}{c}\text { Tidak } \\
\text { Lengkap }\end{array}$} & p value \\
\cline { 2 - 4 } & $\mathbf{n}$ & $\mathbf{\%}$ & $\mathbf{n}$ & $\%$ & \\
\hline Bekerja & 8 & 20 & 9 & 22,5 & \\
Tidak bekerja & 16 & 40 & 7 & 17,5 & \multirow{2}{*}{0,739} \\
\hline Total & 24 & 60 & 16 & 40 & \\
\hline
\end{tabular}

Pada table dapat dilihat bahwa status imunisasi dasar lengkap paling banyak di temukan pada 
kelompok ibu yang tidak bekerja sebanyak 16 orang (40\%) dengan hasil uji statistik diperoleh $\mathrm{p}$ value $(0,739)$.

Analisis Hubungan Faktor Paritas Ibu dengan Status Imunisasi Dasar pada Anak Usia 12-24 Bulan

Penelitian yang dilakukan tentang analisis hubungan faktor jumlah anak ibu dengan status imunisasi dasar pada anak usia 12-24 bulan diperoleh hasil seperti pada tabel dibawah ini :

Tabel 7 Analisis Hubungan Faktor Paritas Ibu dengan Status Imunisasi Dasar pada Anak Usia 12-24 Bulan

\begin{tabular}{cccccc}
\hline \multirow{3}{*}{$\begin{array}{c}\text { Jumlah } \\
\text { Anak }\end{array}$} & \multicolumn{3}{c}{ Status Imunisasi Dasar } & \multirow{3}{*}{ Lengkap } & \multicolumn{2}{c}{ Tidak } & \multirow{2}{*}{ Lengkap } & value \\
\cline { 2 - 5 } & $\mathbf{n}$ & $\mathbf{\%}$ & $\mathbf{n}$ & $\mathbf{\%}$ & \\
\hline Primipara & 11 & 27,5 & 3 & 7,5 & \multirow{2}{*}{0,155} \\
Multipara & 13 & 32,5 & 13 & 32,5 & \\
\hline Total & 24 & 60 & 16 & 40 & \\
\hline
\end{tabular}

Pada table dapat dilihat bahwa status imunisasi dasar lengkap paling banyak di temukan pada kelompok ibu dengan jumlah anak dengan multipara sebanyak 16 orang $(40 \%)$ dengan hasil uji statistik diperoleh $\mathrm{p}$ value $(0,155)$.

Analisis Hubungan Faktor Penghasilan dengan Status Imunisasi Dasar pada Anak Usia 12-24 Bulan

Penelitian yang dilakukan tentang analisis hubungan faktor penghasilan ibu dengan status imunisasi dasar pada anak usia 12-24 bulan diperoleh hasil seperti pada tabel dibawah ini :

Tabel 8 Analisis Hubungan Faktor Penghasilan dengan Status Imunisasi Dasar pada Anak Usia 12-24 Bulan

\begin{tabular}{|c|c|c|c|c|c|}
\hline \multirow{3}{*}{ Penghasilan } & \multicolumn{4}{|c|}{$\begin{array}{c}\text { Status Imunisasi } \\
\text { Dasar } \\
\end{array}$} & \multirow{3}{*}{ p value } \\
\hline & \multicolumn{2}{|c|}{ Lengkap } & \multicolumn{2}{|c|}{$\begin{array}{c}\text { Tidak } \\
\text { Lengkap }\end{array}$} & \\
\hline & $\mathbf{n}$ & $\%$ & $\mathbf{n}$ & $\%$ & \\
\hline $\begin{array}{l}\text { Menengah } \\
\text { Kebawah }\end{array}$ & 8 & 20 & 10 & 25 & \multirow{2}{*}{0,136} \\
\hline $\begin{array}{l}\text { Menengah } \\
\text { Keatas }\end{array}$ & 16 & 40 & 6 & 15 & \\
\hline Total & 24 & 60 & 16 & 40 & \\
\hline
\end{tabular}

Pada table dapat dilihat bahwa status imunisasi dasar lengkap paling banyak di temukan pada tingkat penghasilan menengah keatas sebanyak 16 orang (40\%) dengan hasil uji statistik diperoleh $\mathrm{p}$ value $(0,136)$.
Analisis Hubungan Faktor Pengetahuan Ibu dengan Status Imunisasi Dasar pada Anak Usia 1224 Bulan

Penelitian yang dilakukan tentang analisis hubungan faktor pengetahuan ibu dengan status imunisasi dasar pada anak usia 12-24 bulan diperoleh hasil seperti pada tabel dibawah ini :

Tabel 9 Analisis Hubungan Faktor Pengetahuan Ibu dengan Status Imunisasi Dasar pada Anak Usia 12-24 Bulan

\begin{tabular}{cccccc}
\hline \multirow{2}{*}{$\begin{array}{c}\text { Pengetahu } \\
\text { an }\end{array}$} & \multicolumn{2}{c}{ Status Imunisasi Dasar } & \\
\cline { 2 - 4 } & \multicolumn{2}{c}{ Lengkap } & \multicolumn{2}{c}{$\begin{array}{c}\text { Tidak } \\
\text { Lengkap }\end{array}$} & \multirow{p}{*}{$\boldsymbol{p}$ value } \\
\cline { 2 - 4 } & $\mathbf{n}$ & $\mathbf{\%}$ & $\mathbf{n}$ & $\mathbf{\%}$ & \\
\hline Baik & 5 & 12,5 & 8 & 20 & \multirow{2}{*}{0,113} \\
Kurang & 19 & 47,5 & 8 & 20 & \\
\hline Total & 24 & 60 & 16 & 40 & \\
\hline
\end{tabular}

Pada table dapat dilihat bahwa status imunisasi dasar lengkap paling banyak di temukan pada tingkat penghasilan menengah keatas sebanyak 16 orang (40\%) dengan hasil uji statistik diperoleh $\mathrm{p}$ value $(0,113)$.

\section{PEMBAHASAN}

a. Hubungan Faktor Usia Ibu Dengan Status Imunisasi Dasar Pada Anak Usia 12-23 Bulan

Hasil penelitian menunjukkan tidak ditemukan hubungan yang bermakna antara umur ibu dengan status imunisasi dasar pada anak. Sama halnya dengan hasil penelitian Gunawan (2009) yang menyatakan bahwa tidak ada hubungan antara karakteristik ibu berupa pendidikan, sikap, umur, penghasilan dan paritas terhadap kelengkapan status imunisasi bayi. ${ }^{(8)}$

Hasil penelitian ini juga sesuai dengan penelitian Lienda (2009) dalam penelitiannya didapatkan hasil uji statistik p-value 0,109 bahwa tidak ada hubungan yang bermakna secara signifikan antara usia ibu dengan status imunisasi dasar. ${ }^{(6)}$

Kebijakan program kesehatan keluarga dikatakan bahwa usia yang aman bagi seorang ibu untuk melahirkan anak adalah 20-35 tahun. Seiring dengan itu mengacu kepada penelitian ini, sosialisasi program kesehatan dapat memberikan motivasi dalam meningkatkan kelemgkapan imunisasi sebelum berusia 1 tahun dimasa yang akan datang.

Hasil pengamatan didapatkan bahwa kurangnya dukungan keluarga untuk melengkapi imunisasi,hal ini dikarenakan keluarga takut bayinya akan sakit setelah diimunisasi, ibu yang berusia lebih muda yang baru memiliki anak biasanya cenderung memberikan perhatian yang lebih terhadap anaknya, termasuk kebutuhan akan pelayanan kesehatan. Peningkatan usia ibu mungkin saja diikuti dengan bertambahnya jumlah anak dan meningkatkan 
kesibukan akan mempengaruhi motivasi dan mengurangi ketersediaan waktu bagi ibu untuk memberikan pelayanan kesehatan terhadap anaknya.

\section{b. Hubungan Faktor Tingkat Pendidikan Ibu Dengan Status Imunisasi Dasar Pada Anak Usia 12-23 Bulan}

Hasil penelitian tidak di temukan hubungan yang bermakna antara tingkat pendidikan ibu dengan status imunisasi dasar pada anak. Berbdeda dengan hasil penelitian Fatmayati, (2009) yang menyatakan bahwa semakin tinggi pendidikan ibu semakin tinggi tingkat pengetahuan ibu tentang imunisasi, maka semakin tinggi pula kesadaran ibu untuk membawa anaknya untuk memperoleh imunisasi sehingga sangat berperan dalam kelengkapan imunisasi anak.

Namun, hasil penelitian ini sesuai dengan hasil penelitian Ningrum (2008) yang meneliti tentang Faktor-Faktor Yang Mempengaruhi Kelengkapan Imunisasi Dasar, pada pendidikan ibu tidak mempunyai hubungan yang signifikan terhadap kelengkapan imunisasi dasar pada bayi dengan nilai $\mathrm{p}$ value 0,869 . Selain itu penelitian ini juga sesuai dengan hasil penelitian Sidibyo (2007), yang meneliti tentang Profil Status Imunisasi Dasar Balita di Poliklinik Umum Departemen Ilmu Kesehatan Anak di Rumah Sakit Cipto Mangunkusumo Jakarta yang menyatakan bahwa meskipun pendidikan ibu ataupun orang tua bayi berada dalam kategori sedang atau tinggi tidak ada hubungannya dengan status imunisasi dasar pada bayi.

Menurut analisa penelliti dari tempat penelitian didapatkan bahwa lokasi masih jauh dari daerah perkotaan yang memudahkan akses informasi mengenai segala sesuatu yang penting seperti halnya dibidang kesehatan seperti halnya imunisasi. Alasan yang dikemukakan orang tua untuk tidak melengkapi imunisasi sebagian besar adalah anak sering sakit (misalnya demam dan batuk/pilek), dan masih ada yang menyatakan karena cemas/takut dan tidak tahu.

\section{c. Hubungan Faktor Pekerjaan Ibu Dengan Status Imunisasi Dasar Pada Anak Usia 12-23 Bulan}

Hasil penelitian menunjukkan tidak ditemukan hubungan yang bermakna secara statistik antara pekerjaan ibu dengan status imunisasi dasar pada anak. Hal ini sesuai dengan hasil penelitian Yusuf (2007) yang meneliti tentang pengetahuan, sikap dan perilaku ibu bekerja dan ibu tidak bekerja tentang imunisasi menyatakan bahwa pekerjaan ibu tidak ada hubungan dan pengaruhnya dengan kelengkapan status imunisasi bayi dengan nilai $p$ value 0,492 .

Hasil penelitian ini juga sesuai dengan Lienda (2009) pekerjaan ibu dengan kategori ibu bekerja dengan tidak bekerja, tidak ada hubungan pekerjaan ibu dengan kelengkapan imunisasi nilai pvalue $=0,250$. Hal ini disebabkan karena ibu yang bekerja proporsi anak yang tidak mendapatkan imunisasi lengkap hampir tidak berbeda dengan ibu yang bekerja. Reza (2006) hasil penelitiannya tidak ditemukan hubungan antara pekerjaan ibu terhadap status imunisasi dasar pada anaknya dengan nilai pvalue $=0,902$. Proporsi anak yang tidak mendapatkan imunisasi dasar lengkap hampir tidak berbeda dengan anak yang telah lengkap imunisasi dasarnya pada setiap kelompok pekerjaan ibu. Hal ini dikarenakan yang terpilih menjadi responden adalah ibu-ibu yang bekerja pada sektor non formal atau sebagai ibu rumah tangga saja. Status kerja yang demikian akan memberikan waktu yang lebih banyak kepada ibu untuk membawa anaknya mendapatkan imunisasi di pos pelayanan terpadu.

Selain itu, hasil penelitian ini sesuai dengan hasil penelitian Ali (2003) yang meneliti tentang pengetahuan, sikap dan perilaku ibu bekerja dan ibu tidak bekerja yang menyatakan bahwa ternyata di kalangan ibu tidak bekerja sikap dan perilaku mereka tentang imunisasi lebih baik dibanding ibu yang bekerja. Beberapa kesalah pahaman tentang imunisasi masih saja dijumpai. Dengan kata lain ibu yang tidak bekerja lebih sering membawa bayinya imunisasi, sehingga status imunisasi dasar pada bayinya lebih lengkap dibandingkan ibu yang bekerja.

Hasil wawancara dan observasi dilapangan, peneliti menemukan bahwa alasan status imunisasi pada bayi responden tidak lengkap adalah karena ibu harus menunggu giliran, responden menganggap bahwa masih banyak pekerjaan mereka yang harus dilakukan daripada harus berlama-lama menunggu giliran untuk mendapatkan imunisasi anaknya.

\section{d. Hubungan Faktor Paritas Ibu Dengan Status Imunisasi Dasar Pada Anak Usia 12-23 Bulan}

Penelitian ini menunjukkan tidak di temukan hubungan yang bermakna secara statistik antara jumlah anak ibu dengan status imunisasi dasar pada anak. Hal ini sesuai dengan hasil penelitian Isatin (2005) yang menyatakan bahwa status imunisasi bayi yang tidak lengkap lebih banyak ditemui pada ibu yang mempunyai banyak anak, sehingga tidak terdapat hubungan antara jumlah anak dengan status kelengkapan imunisasi anak.

Kunjungan ke pos pelayanan imunisasi terkait dengan ketersediaan waktu bagi ibu untuk mencari pelayanan imunisasi terhadap anaknya. Oleh karena itu jumlah anak dapat mempengaruhi ada tidaknya waktu bagi ibu meninggalkan rumah untuk mendapatkan pelayanan imunisasi kepada anaknya. Jumlah anak yang banyak membutuhkan banyak waktu bagi ibu untuk mengurus anak-anaknya, sehingga ketersediaan waktu bagi ibu untuk mendatangi tempat pelayanan imunisasi tidak banyak.

Hasil penelitian ini juga dengan Lienda (2009) tidak ada hubungan jumlah anak dengan kelengkapan imunisasi dengan nilai $p=0,434$. Begitu juga dengan penelitian Reza (2006) tidak ada hubungan jumlah anak yang dimiliki tidak begitu berpengaruh nilai $\mathrm{p}$ value $=0,168$ terhadap kelengkapan status imunisasi anak yang berada di puskesmas Pauh. 
Selain itu hasil penelitian ini juga sesuai dengan hasil penelitian Rahmat (2003) yang meneliti tentang faktor-faktor yang mempengaruhi status imunisasi, menyatakan bahwa jumlah anak (paritas) tidak berhubungan secara bermakna dengan kelenkapan status imunisasi dasar pada bayi.

Setelah dilakukan observasi, ternyata responden sering lupa untuk membawa bayinya imunisasi sehingga bayinya tidak mendapatkan imunisasi sesuai jadwal yang mengakibatkan status imunisasi dasar pada anaknya tidak lengkap.

\section{e. Hubungan Faktor Penghasilan Dengan Status} Imunisasi Dasar Pada Anak Usia 12-23 Bulan

Factor penghasian dengan status imunisasi dasar pada anak tidak ditemukan hubungan yang bermakna. Hal ini sesuai dengan hasil penelitian Gunawan (2009) yang meneliti tentang Pengaruh Karakteristik Ibu Dan Sosial Lingkungan Terhadap Pemberian Imunisasi menyatakan tidak ada hubungan antara karakteristik ibu berupa pendidikan, sikap, umur, penghasilan dan paritas terhadap kelengkapan status imunisasi bayi.

Hasil penelitian ini juga sesuai dengan hasil penelitian Sudibyo (2007), yang meneliti tentang Profil Status Imunisasi Dasar Balita di Poliklinik Umum Departemen Ilmu Kesehatan Anak di Rumah Sakit Cipto Mangunkusumo Jakarta yang menyatakan meskipun penghasilan orangtua berada dalam kategori menengah dan tinggi, tetapi tidak mempunyai hubungan yang bermakna dalam kelengkapan status imunisasi dasar pada bayi.

Hasil penelitian dilapangan, responden menyatakan bahwa mereka kurang percaya akan manfaat imunisasi. Sehingga menurut responden bayinya akan tetap sehat walaupun tidak diimunisasi, yang mengakibatkan status imunisasi dasar pada bayinya tidak lengkap.

\section{f. Hubungan Faktor Pengetahuan Dengan Status Imunisasi Dasar Pada Anak Usia 12-23 Bulan}

Hasil penelitian menunjukkan pengetahuan ibu tidak ada hubungan yang signifikan antara dengan status imunisasi anak, dengan hasil uji statistik diperoleh nilai $\mathrm{p}=0,113$.

Penelitian ini tidak sejalan dengan Reza (2006) ada hubungan pengetahuan ibu dengan kelengkapan imunisasi dasar dengan nilai $p=0,036$. Hubungan antara status imunisasi dasar pada bayi usia 0-12 bulan dengan pengetahuan ibu tentang imunisasi, pendidikan orangtua, pendapatan orangtua, dan jumlah anak. Diantara beberapa faktor tersebut pengetahuan ibu tentang imunisasi merupakan suatu faktor yang sangat erat hubungannya dengan status imunisasi anak.

\section{KESIMPULAN}

Tidak terdapat hubungan yang bermakna antara umur, pendidikan pekerjaan, paritas ibu, penghasilan ibu dengan status imunisasi dasar pada anak $(p>0,05)$. Pengetahuan ibu sebagian besar adalah pengetahuan kurang sebanyak 67,5\%. Tidak ada hubungan yang bermakna antara pengetahuan ibu dengan dengan status imunisasi dasar pada anak $(p=0,113)$.

\section{DAFTAR PUSTAKA}

1. Sardjunani, N., \& Tuwo,L.D., 2010. Peta Jalan Percepatan Pencapaian Tujuan Pembanguna Millenium, Kementerian Perencanaan Pembangunan Nasional/Badan Perencanaan Pembangunan Nasional (BAPPENAS). Jakarta.

2. Ranuh, I.G.N., Suyitno, H., Hadinegoro, S.R.S., Ismael, S., Rahajoe, N.N., Matondang, C.S., et al. (2008). Pedoman Imunisasi di Indonesia. Jakarta : Satgas Imunisasi-Ikatan Dokter Anak Indonesia.

3. Priyono Y (2010). Merawat Bayi Tanpa Baby Sitter, Yogyakarta: Medika Pressindo.

4. Departemen Kesehatan RI (2010), Buku Kesehatan Ibu Dan Anak, Indonesia Sehat 2010, Jakarta: Tidak dipublikasikan

5. Kementerian Kesehatan RI (2010), Profil Kesehatan Indonesia Tahun 2009, Jakarta: Tidak dipublikasikan.

6. Riskesdas, (2010). Membumikan Millenium Development Goals(MDGs) di Seantero Nusantara Paket A, Badan Pusat Statistik. Jakarta.

7. Lienda, (2009). Faktor-faktor yang Berhubungan dengan Kelengkapan Imunisasi pada Anak Usia 12-23 Bulan di Jawa Barat dan Jawa Tengah Tahun 2007. Depok : Skripsi FKM UI.

8. Reza, (2006). Faktor-faktor yang Berhubungan dengan Status Imunisasi Dasar pada Anak di Puskesmas Pauh Kota Padang Tahun 2006. Depok : Tesis FKM UI. http//www.digilib.ui.ac.id/opac/themes/libri2/ diperoleh 11 November 2011.

9. Gunawan, (2009). Pengaruh Karakteristik Ibu dan Lingkungan Sosial Budaya Terhadap Pemberian Imunisasi Hepatitis B pada Bayi 0-7 Hari di Kabupaten Langkat. Medan: Tesis Pascasarjana USU. 